\title{
Determinant Mapping on the Knowledge of Barangay Police Safety Officers on Their Duties and Responsibilities in San Roque, San Isidro, Nueva Ecija: A Basis for Re-Engineering Action Programs through Suc Intervention
}

\author{
Januaryn Jose B. Aydinan \\ College of Criminology-Nueva Ecija University of Science and Technology, Cabanatuan, Nueva Ecija, Philippines \\ Email: zedka_jen27@yahoo.com
}

How to cite this paper: Aydinan, J.J.B. (2021) Determinant Mapping on the Knowledge of Barangay Police Safety Officers on Their Duties and Responsibilities in San Roque, San Isidro, Nueva Ecija: A Basis for Re-Engineering Action Programs through Suc Intervention. Open Access Library Journal, 8: e7939.

https://doi.org/10.4236/oalib.1107939

Received: September 8, 2021

Accepted: October 9, 2021

Published: October 12, 2021

Copyright $\odot 2021$ by author(s) and Open Access Library Inc.

This work is licensed under the Creative Commons Attribution International License (CC BY 4.0).

http://creativecommons.org/licenses/by/4.0/

\begin{abstract}
Barangay enforcers are in the vanguard of the effort to maintain peace and order in every barangay in the country. This paper was written to explore the level of knowledge of barangay police safety officers in the performance of their duties and responsibilities. This study ought to determine the respondents' demographic profile, their level of knowledge about their duties and obligations, their first responder's function, as well as patrolling and hazard identification duties. This study made use of the descriptive-correlational design of quantitative research by utilizing a researcher-made instrument which is in the form of a questionnaire checklist to scientifically measure the level of knowledge of barangay enforcers and an interview guide to determine the veracity of their answers. The respondents of this study are the existing enforcers of Barangay San Roque, San Isidro, Nueva Ecija, Philippines. Nineteen barangay enforcers were present at the barangay hall when the instrument was distributed. The result of the study disclosed that the majority of the barangay enforcers belong to age above 55, male, married, elementary graduates, high school undergraduates, high school graduates, have $1-3$ years of experience as barangay enforcers and receive only 1 - 3 training which is related to their functions as enforcers. Based on the data gathered, the respondents are highly knowledgeable when it comes to their duties and responsibilities. The respondents professed that they are highly knowledgeable about their role as first responders. Allegedly, they are likewise highly knowledgeable in patrolling and hazard identification duties. That being said, it is highly suggested that the proposed training plan be funded and implemented to im-
\end{abstract}


prove the barangay enforcers' knowledge and skills in the areas highlighted as

needing improvement.

\section{Subject Areas}

Information Science, Sociology

\section{Keywords}

Barangay Enforcers, Duties and Responsibilities, First Responder's Role, Hazard Identification, Level of Knowledge, Patrolling

\section{Introduction}

Zeal to serving on the respective post of duty is a good characteristic of public servants that shows their love to their constituents and countrymen. This trait is the fuel that enables civil servants to drive and lead forward. Over and above dedication, steering from love develops the art of leadership continuously. Servant leadership argues that if leaders practice love, they will manifest the character to make people want to follow them. Of course, all this talk of love and character sounds mushy [1]. Nevertheless, other advocates of servant leadership also argue that leadership begins with character. [2] argues that leaders must first overcome their ego's desire to be served and learn to focus on serving others. They contend that a heart motivated by self-interest cannot be the heart of an effective leader.

Moreover, possessing a good character in leadership wins respect, trust and establishes the community's continued vitality. Consequently, when one leads, an attribute that conforms to the norms of society is needed. As [3] argues, leadership is a skill that is learned by first developing a character based on moral maturity and the commitment to do the right thing. These and other servant leadership advocates emphasize that leadership is much more about the kind of person one is than it is about techniques and practices. In addition, empowerment activities seek to enhance intrinsic motivation and its contribution to creation; this implies that public servants' innovation often relies on their inner interests, their enjoyment of job assignments, and their ability to consider each other's viewpoints [4] [5]. Improving one's services benefits the state, and the benefit of the state is the primary goal of a public servant. However, evaluating oneself to improve services begins with the noble discovery of weakness points, attributes, and determinants. Values are chosen while passing through life stages [6]. Skills and abilities, on the other hand, are essential aspects of an organization. These are needed to sustain and develop one's knowledge concerning their duties in rendering services to the people. To improve the skills and abilities of all public servants, sets of training, seminars, and workshops should be carried out to ensure the efficacy of their performance of their duties. 
In the Philippine setting, Barangays serve as the smallest administrative region, governed by one leader: the Barangay Chairman (according to the law)/Barangay Chairperson (GAD Advocates)/Barangay Captain (street term). The Punong Barangay (Barangay Chairperson) plays a vital role in preparing and executing government policies, initiatives, and services for the citizens. The Barangay Captain serves as the administrator of one barangay. With the help of barangay councilors, his primary duty is to control the peace, order, and security of his or her area of jurisdiction. However, such a position is still a tremendously heavy obligation to be carried by the shoulder of only one person. This is because of the considerable number of families within the barangay and the vastness of its territory. To make the performance of such obligation more efficient, the Barangay Captain has the power to appoint barangay police officers or "barangay tanods" to screen the peripheries of "puroks" or zones of the entire barangay and to extend the barangay services, particularly in maintaining peace, security, and order, through crime responding, patrolling, and hazard identification.

The patrol force is considered the core of the police departments in any community. Its existence lessens the necessity for organizing specialized operating units because these patrol forces directly deal with society. Police executives and local officials are cognizant that the patrol force is the most important element of the police department [7]. In relation to this, the barangay enforcers are force multipliers of the Philippine National Police, with the fundamental duty of patrolling and responding to incidents within their Area of Responsibility (AOR). This is true because the characteristics of community policing are common among jurisdictions [8]. Examples of these are the involvement of the community in the performance of police jobs; the relevant assignment of police officers to a neighborhood to develop better relationships; the setting of police goals based on real needs and desires-proper application of the above would encourage an organized and peaceful society, and barangay enforcers contribute to it.

This study endeavors to determine the level of knowledge of the barangay police officers about their duties and responsibilities, as it is crucial to decide on all factors and contributors to the performance efficiency level of the said workers. In other words, the purpose of this research study is to assist barangay police officers by performing determinant mapping to discern the weak attribute points, which numbers all attributes and identifies related matters per job specification to exact the actual controllable and uncontrollable points that need enhancement, intervention, and plan.

\section{Objectives of the Study}

To strengthen the performance of the barangay enforcers as police officers in the basic unit of government, this study aims to assess the level of knowledge on the duties and responsibilities, first responder's role, and patrolling and hazard 
identification duties of barangay enforcers in San Roque, San Isidro, Nueva Ecija. Specifically, this study has the following objectives:

1) The demographic profile of the respondents in terms of:

a) Age;

b) Gender;

c) Civil Status;

d) Highest Educational Attainment;

e) Years of Experience as Barangay Enforcers; and,

f) No. of Training attended related to their functions as Barangay Enforcers.

2) The barangay enforcers level of knowledge on:

a) Their Duties and Responsibilities;

b) First Responder's Role; and,

c) Patrolling and Hazard Identification.

3) To determine if there is a significant relationship between the level of knowledge of the barangay enforcers and their demographic profile;

4) Problems encountered by the barangay enforcers in performing their duties and responsibilities, as first responders and in patrolling and identifying hazards;

5) To propose a Training Plan to improve their knowledge on:

a) Their Duties and Responsibilities;

b) First Responder's Role; and,

c) Patrolling and Hazard Identification.

\section{Methodology}

On the basis of the stated problem, the research design employed by the researcher was the descriptive-correlational design of the quantitative research. Where there is no prior knowledge of a phenomenon, descriptive designs identify what is present, determine the frequency in which it occurs, and classify the data [9]. On the other hand, correlational designs involve the systematic investigation of the nature of relationships or associations between and among variables which are typically cross-sectional [10]. The participants of the study were the nineteen (19) barangay enforcers of the Barangay San Roque, San Isidro, Nueva Ecija in the Philippines. This study made use of the descriptive-correlational design of quantitative research by utilizing a researcher-made instrument which was in the form of a questionnaire checklist to scientifically measure the level of knowledge of barangay enforcers and an interview guide to determine the veracity of their answers. The following numerical and adjectival values were used (Table 1).

In this paper, the respondents' demographic profile, was determined using the frequency and percentage; while their level of knowledge about their duties and responsibilities, their first responder's function, as well as patrolling and hazard identification duties were determined using the weighted mean. The weighted mean involves multiplying each data point in a set by a value which is determined by some characteristic of whatever contributed to the data point [11]. 
Table 1. Numerical and adjectival values of this study.

\begin{tabular}{ccc}
\hline Ranges & Rate & $\begin{array}{c}\text { Level of Knowledge their Duties and Responsibilities, } \\
\text { First Responder's Role and Patrolling } \\
\text { and Hazard Identification Duties }\end{array}$ \\
\hline $4.20-5.00$ & 5 & Highly Knowledgeable \\
$3.40-4.19$ & 4 & Knowledgeable \\
$2.60-3.39$ & 3 & Moderately Knowledgeable \\
$1.80-2.59$ & 2 & Fairly Knowledgeable \\
$1.00-1.79$ & 1 & Not Knowledgeable \\
\hline
\end{tabular}

Data analysis of Microsoft Excel 2010 and Statistical Package for Social Sciences (SPSS) were employed for computations of the gathered information of the questionnaire from the respondents.

\section{Results and Discussion}

This section presents the results obtained from the survey conducted regarding the barangay enforcers' level of knowledge of their duties and responsibilities, first responder's role, and patrolling and hazard identification duties. Furthermore, an interview guide was also established to determine the veracity of their answers.

\subsection{The Demographic Profile of the Respondents}

Table 2 shows the demographic profile of the respondents and the data portrays that the majority of the participants or $36.48 \%$ of the respondents' age range is above 55 . This simply means that the majority of barangay enforcers are mature individuals who are capable of carrying out their duties and obligations in the best interests of their community [12].

As presented in Table 2, it can be observed that the majority of the respondents, or $84.21 \%$ are male. This just serves to demonstrate that preservation of peace is a male-dominated endeavor. These assumptions and ideas are especially concerning when maintained by male officers, as some evidence suggests that a masculine police culture still exists in law enforcement [13] [14].

Meanwhile, it can be noticed that all of the respondents or $100.00 \%$ are already married. This just entails that the majority of barangay enforcers are capable of performing their duties and responsibilities in their barangay, as part of the community is also their own family.

On the other hand, the majority of the respondents, or $21.05 \%$ are elementary graduates, high school undergraduates, and high school graduates. The lack of higher education of the barangay enforcers signifies that they need training and seminars to be prepared with the necessary skills and information to preserve peace and order in their respective jurisdictions.

It can also be noticed from the table above that the majority of the respondents or $52.63 \%$ only have $1-3$ years of experience as barangay enforcers. It just 
Table 2. Profile of the respondents.

\begin{tabular}{|c|c|c|}
\hline Age Range & Frequency & Percentage \\
\hline Below 26 & 0 & 0.00 \\
\hline $26-31$ & 0 & 0.00 \\
\hline $31-35$ & 2 & 10.53 \\
\hline $36-40$ & 2 & 10.53 \\
\hline $41-45$ & 2 & 10.53 \\
\hline $46-50$ & 1 & 5.26 \\
\hline $51-55$ & 5 & 26.32 \\
\hline Above 55 & 7 & 36.84 \\
\hline Total & 19 & 100.00 \\
\hline Sex & Frequency & Percentage \\
\hline Male & 16 & 84.21 \\
\hline Female & 3 & 15.79 \\
\hline Total & 19 & 100.00 \\
\hline Civil Status & Frequency & Percentage \\
\hline Single & 0 & 0.00 \\
\hline Married & 19 & 100.00 \\
\hline Widow/er & 0 & 0.00 \\
\hline Total & 19 & 100.00 \\
\hline Highest Educational Attainment & Frequency & Percentage \\
\hline Elementary Undergraduate & 3 & 15.79 \\
\hline Elementary Graduate & 4 & 21.05 \\
\hline High School Undergraduate & 4 & 21.05 \\
\hline High School Graduate & 4 & 21.05 \\
\hline Vocational/Technical Graduate & 2 & 10.53 \\
\hline College Undergraduate & 1 & 5.26 \\
\hline College Graduate & 1 & 5.26 \\
\hline Post Graduate & 0 & 0.00 \\
\hline Total & 19 & 100.00 \\
\hline Years of Experience as Barangay Enforcer & Frequency & Percentage \\
\hline $1-3$ years & 10 & 52.63 \\
\hline $4-6$ years & 1 & 5.26 \\
\hline 7 - 9 years & 2 & 10.53 \\
\hline $10-12$ years & 1 & 5.26 \\
\hline Above 12 years & 5 & 26.32 \\
\hline Total & 19 & 100.00 \\
\hline $\begin{array}{l}\text { No. of Training Attended which is Related to their } \\
\text { Functions as Barangay Enforcers }\end{array}$ & Frequency & Percentage \\
\hline $1-3$ & 13 & 68.42 \\
\hline $4-6$ & 4 & 21.05 \\
\hline $7-9$ & 2 & 10.53 \\
\hline Above 9 & 0 & 0.00 \\
\hline Total & 19 & 100.00 \\
\hline
\end{tabular}


proves that the majority of them still require ongoing training. This is true since, during the interview, one of the barangay enforcers revealed that when the Barangay Captain is replaced after the election, certain incumbent barangay enforcers who do not support the elected Barangay Chairman are also replaced. This is a common practice in the Philippines that might stifle the development of a Barangay Peace Officer.

Lastly, it can be perceived from the data above that majority of the respondents or $68.42 \%$ have attended only 1 - 3 training which is related to their functions as barangay enforcers. Training and seminar should be conducted to enhance the skills and abilities of any person to ensure the effectiveness of the performance of their duties [15].

\subsection{The Barangay Enforcers' Level of Knowledge}

It can be noticed from the data in Table 3 that the barangay enforcers themselves claimed that they are highly knowledgeable in assisting the police and lupong tagapamayapa in the maintenance of peace and order in their area of responsibility with a weighted mean of 4.74. Executive Order (EO) No. 546 authorized the PNP to deputize the village tanods as force multipliers in the implementation of the peace and order plan, subject to the occurrence of the appropriate Local Chief Executive through the Local Peace and Order Council (LPOC) [16].

At the same time, the barangay enforcers believed that they are highly knowledgeable in the conduct of patrol/ronda in the barangay, in detecting all forms of fire hazards and other public safety hazards/violations, and they can institute corrective measures with their capability and at the same time in coordinating closely with the barangay officials and the police in the campaign against crimes

Table 3. The barangay enforcers level of knowledge on their duties and responsibilities.

\begin{tabular}{|c|c|c|c|}
\hline No. & Item Statement & $\begin{array}{l}\text { Weighted } \\
\text { Mean }\end{array}$ & Verbal Description \\
\hline 1 & Conduct of patrol/ronda in the barangay & 4.63 & Highly Knowledgeable \\
\hline 2 & $\begin{array}{l}\text { Assisting the police and lupong tagapamayapa } \\
\text { in the maintenance of peace and order in the } \\
\text { area of responsibility }\end{array}$ & 4.74 & Highly Knowledgeable \\
\hline 3 & $\begin{array}{l}\text { Detecting all forms of fire hazards and other } \\
\text { public safety hazards/violations and to institute } \\
\text { corrective measure with their capability }\end{array}$ & 4.63 & Highly Knowledgeable \\
\hline 4 & $\begin{array}{l}\text { Conducting surveillance on crime breeding } \\
\text { areas within the barangay/purok and report } \\
\text { their observations/findings to the proper } \\
\text { authorities or through Hotline "117" }\end{array}$ & 4.53 & Highly Knowledgeable \\
\hline 5 & $\begin{array}{l}\text { Coordinating closely with the barangay officials } \\
\text { and the police in the campaign against crimes }\end{array}$ & 4.63 & Highly Knowledgeable \\
\hline & Average Weighted Mean & 4.63 & $\begin{array}{l}\text { Highly } \\
\text { Knowledgeable }\end{array}$ \\
\hline
\end{tabular}


with a weighted mean of 4.63. In the study of [17], the duties of the Barangay Security and Development Officers (BSDOs), also known as the Barangay Tanod, include intelligence gathering, neighborhood monitoring, and rondas. The barangay enforcers' responsibilities are comparable to those of uniformed police officers. Residents acting as members of the ronda team receive and investigate citizen complaints, offer physical security to local officials, and arrange evacuations in emergencies, in addition to reporting suspicious-looking characters and monitoring the neighborhoods like citizens who perform "neighborhood watch" [18].

Still, despite the fact that barangay police, or "tanod," are volunteers, they are willing to risk their lives to safeguard the safety of the people in their own barangays [19]. The PNP's Barangay Peacemaking Action Team (BPAT) is a national program that encourages community empowerment to address real-time response in the event of a need, whether it's for peace and order, security, or rescue [20] [21] [22]. Barangay enforcers, like law enforcers, play a coordinative role in the overall endeavor to address social and economic issues that affect their communities. If truth be told, they assist law enforcement in the fight against criminality, particularly street crime [23].

Lastly, the barangay enforcers also claimed that they are highly knowledgeable in conducting surveillance on crime breeding areas within the barangay/purok and report their observations/findings to the proper authorities or through Hotline "117" with a weighted mean of 4.53. The BPAT uses its authority to resolve conflicts and protect the area from illegal individuals [24]. BPAT, in particular, performs surveillance on crime hotspots, defends property, responds to community issues such as nuisance complaints, assists crime victims, answers call, and manages traffic safety.

To sum it all, it can be mentioned that barangay enforcers in this specific area are confident enough that they are highly knowledgeable on their duties and responsibilities.

The barangay enforcers' level of knowledge in terms of their first responder's role can be viewed in Table 4. The barangay enforcers of San Roque, San Isidro, Nueva Ecija are confident that they are highly knowledgeable in terms of receiving and recording an emergency call and calling the police immediately with a weighted mean of 4.68. According to [25], receiving information/complaints, recording information/complaints, or issuing directives is one of the tasks of barangay enforcers; hence, they must be well-versed in this activity. Generally, community first responders will be asked to respond to security alerts within a six-mile radius of their location while also being alerted to the emergency call.

Concurrently, the barangay enforcers assumed that they are highly knowledgeable in managing the traffic in a vehicular accident with a weighted mean of 4.42. As enforcers, it is their task to secure the scene for responder and motorist safety and conducts traffic control as necessary [26].

The respondents also believed that they are highly knowledgeable in responding to the crime scene immediately with a weighted mean of 4.32. Undeniably, 
Table 4. The barangay enforcers level of knowledge in their first responder's role.

\begin{tabular}{|c|c|c|c|}
\hline No. & Item Statement & $\begin{array}{c}\text { Weighted } \\
\text { Mean }\end{array}$ & Verbal Description \\
\hline 1 & Receiving and recording an emergency call & 4.68 & Highly Knowledgeable \\
\hline 2 & Responding to the crime scene immediately & 4.32 & Highly Knowledgeable \\
\hline 3 & $\begin{array}{l}\text { Giving assistance to the injured/perform first } \\
\text { aid/ bring the injured to the nearest hospital }\end{array}$ & 3.95 & Knowledgeable \\
\hline 4 & Securing the crime scene & 3.89 & Knowledgeable \\
\hline 5 & $\begin{array}{l}\text { Observing and taking note of the time of } \\
\text { arrival, weather condition, surroundings, } \\
\text { persons present, persons arriving and } \\
\text { leaving the scene. }\end{array}$ & 3.84 & Knowledgeable \\
\hline 6 & Managing the traffic in a vehicular accident & 4.42 & Highly Knowledgeable \\
\hline 7 & Calling the police immediately & 4.68 & Highly Knowledgeable \\
\hline 8 & $\begin{array}{l}\text { Turning over the crime scene to the } \\
\text { responding police officers }\end{array}$ & 4.21 & Highly Knowledgeable \\
\hline & Average Weighted Mean & 4.25 & Highly Knowledgeable \\
\hline
\end{tabular}

the barangay enforcers, as first responders are trained persons who respond to an emergency or crisis call within their community [27]. They will respond to emergencies and crises, as well as routine situations as needed; as a result, they must seek professional security advice, training, and management support from specialists in the field.

On the flip side, the participants are just knowledgeable in assisting the injured/perform first aid/bring the injured to the nearest hospital, securing the crime scene, and observing and taking note of the time of arrival, weather condition, surroundings, persons present, persons arriving and leaving the scene with a weighted mean of 3.95, 3.89, 3.84 accordingly. The initial responder, usually a patrol officer, must assess the situation and take action quickly. One priority is assessing the need for medical assistance and arranging for medical help [28]. After the situation has been secured, an officer may assist anyone who requires emergency assistance until medical personnel arrives [29]. The first officer on the scene, like with any other violent crime, must ensure that the victim receives medical assistance [30].

As first responders, they are trained to react quickly in emergencies. Their first responsibility is to make sure that people are safe, which may include evacuation, rescue, crowd control, and medical attention [31].

Lastly, part of their role is to start documenting all information about the collected evidence in the chain of custody document sheet. The chain of custody document sheet contains information such as case number, name of the person who reported the case, address and telephone number, location of the evidence, date/time of collecting the evidence, and a complete description of the item [32]. They should also take note of precise times, such as when they arrived, when the scene was secured, when medical personnel arrived, when the victim was taken, 
and other critical occurrences at the crime scene [33].

To sum it all, it can be declared that barangay enforcers in this specific area are confident enough that they are highly knowledgeable on their first responder's role.

The barangay enforcers' level of knowledge in terms of their patrolling and hazard identification duties can be seen in Table 5. The respondents affirmed that they are highly knowledgeable in the conduct of roving within their assigned area of responsibility with a weighted mean of 4.95. Apart from functioning as visible security in their respective community through ronda patrol activity, barangay enforcers can also perform intelligence monitoring as an extension of law enforcement and the first point of contact for citizens in the barangay [34]. The barangay enforcers as a roving officer will patrol a designated area for the length of time they are on shift. Their role includes a combination of deterring crime by being visible and recognizing occurrences as they occur, if not sooner [35].

The participants also declared that they are highly knowledgeable in reporting identified hazards with a weighted mean of 4.63. It is about providing a safe environment for all residents in the barangay that they report occurrences and hazards in their neighborhood as quickly as possible [36].

In addition to this, the respondents stated that they are highly knowledgeable in identifying hazards within the area of their responsibilities with a weighted mean of 4.58. Every day, barangay enforcers are on the front lines in their community, and they are frequently the first to notice hazards. Identifying hazards and reporting them is the first and most important step to improving safety and health in their area of responsibility [37].

Moreover, the respondents also acknowledged that they are highly knowledgeable in taking note of identified hazards with a weighted mean of 4.53. To effectively enforce the law, barangay enforcers must be proficient in identifying and recording potential hazards in their respective areas of responsibility.

However, the barangay enforcers confirmed that they are just knowledgeable

Table 5. The barangay enforcers level of knowledge in their patrolling and hazard identification duties.

\begin{tabular}{|c|c|c|c|}
\hline No. & Item Statement & $\begin{array}{l}\text { Weighted } \\
\text { Mean }\end{array}$ & Verbal Description \\
\hline 1 & $\begin{array}{l}\text { The conduct of roving within area of } \\
\text { responsibility }\end{array}$ & 4.95 & Highly Knowledgeable \\
\hline 2 & $\begin{array}{l}\text { Identifying hazards within area of } \\
\text { responsibilities (AOR) }\end{array}$ & 4.58 & Highly Knowledgeable \\
\hline 3 & Taking note of identified hazards & 4.53 & Highly Knowledgeable \\
\hline 4 & Reporting identified hazards & 4.63 & Highly Knowledgeable \\
\hline 5 & $\begin{array}{l}\text { Handling incidents encountered during } \\
\text { the conduct of ronda }\end{array}$ & 4.16 & Knowledgeable \\
\hline & Average Weighted Mean & 4.57 & Highly Knowledgeable \\
\hline
\end{tabular}


in terms of handling incidents encountered during the conduct of ronda with a weighted mean of 4.16. As roving patrol officers, barangay enforcers must respond to crises immediately and use their training and experience to go directly to a spot, assess the situation, and find the best strategy to maintain control and keep everyone protected [38]. This is why they must be well-versed in how these actions should be carried out effectively with the assistance of individuals who are experts in the sector.

To sum it all, it can be declared that barangay enforcers in this specific area are confident enough that they are highly knowledgeable in terms of their patrolling and hazard identification duties.

\subsection{Significant Relationship between the Level of Knowledge of the Barangay Enforcers and Their Demographic Profile}

Table 6 shows the relationship between the level of knowledge of the barangay enforcers and their demographic profile. It can be observed that the level of knowledge of the barangay enforcers is correlated to their age which implies that the higher the age, the higher the level of their knowledge. Although it is commonly considered that wisdom comes with age and experience, factual and circumstantial evidence suggests that this is not always the case [39] but the fact that adults have a higher probability to be wiser than younger individuals because growth in wisdom is assumed to take time cannot be denied [40].

The level of knowledge of the barangay enforcers is significantly related to their years of experience as enforcers which is indicated in the table above. This only denotes that the longer the years in service, the higher the level of knowledge. The majority of specialists and laypeople think that learning from life experiences is necessary for wisdom to emerge but in reality, wisdom may only increase with age for those who actively seek it out and can learn from their life experiences [41].

On the opposite side, the respondents' sex, civil status, highest educational attainment, and the number of training attended related to their function as barangay enforcers do not have any significant relationship to the level of their

Table 6. Relationship between the level of knowledge of the Barangay enforcers and their demographic profile.

\begin{tabular}{|c|c|c|c|}
\hline \multirow{2}{*}{ Profile of the Respondents } & \multicolumn{2}{|c|}{ Level of Knowledge } & \multirow{2}{*}{ Decision } \\
\hline & r-value & $\mathrm{p}$-value & \\
\hline Age Range & $0.645^{\star *}$ & 0.003 & Significant Relationship \\
\hline Sex & -0.132 & 0.590 & No Significant Relationship \\
\hline Civil Status & 0.00 & & No Significant Relationship \\
\hline Highest Educational Attainment & 0.228 & 0.348 & No Significant Relationship \\
\hline $\begin{array}{l}\text { Years of Experience as Barangay } \\
\text { Enforcer }\end{array}$ & $0.543^{*}$ & 0.016 & Significant Relationship \\
\hline $\begin{array}{l}\text { No. of Training attended related to } \\
\text { your function as Barangay Enforcer }\end{array}$ & -0.092 & 0.707 & No Significant Relationship \\
\hline
\end{tabular}


knowledge in their duties and responsibilities, first responder's role and patrolling and hazard identification duties.

\subsection{Problems Encountered by the Barangay Enforcers in Performing Their Duties and Responsibilities, as First Responders and in Patrolling and Identifying Hazards}

Since barangay enforcers are in charge of maintaining peace and order in each barangay, it cannot be disputed that they face and overcome problems in carrying out their duties and obligations. As proof, during the interview with some of them, they stated some of the frequent issues they face regularly. Some of the respondents revealed that their patrol vehicle is not well-maintained. It can be claimed that law enforcement and public safety agencies face a common difficulty in the allocation and dispatch of emergency vehicles [42]. [43] added that while vehicles under both management plans received equally adequate preventive maintenance, police pool cars like patrol vehicles were significantly more likely to experience breakdowns, thus requiring more frequent shop visits per mile.

Lack of personal equipment like communication devices and raincoats that are very essential in the conduct of patrol is another problem cited by the barangay enforcers during the interview. In the course of the patrol, monitoring is an important task. Because of poor communication and a lack of equipment among the individuals assigned to this job, this monitoring is frequently insufficient, resulting in serious accidents [44].

As a result of their exposure to public locations, barangay enforcers are not free from the dangers posed by the COVID-19. Concerning this, the barangay enforcers stated that many residents are violating safety protocols such as wearing facemasks on the street during the pandemic, which is causing them a lot of grief. Despite mask regulations in numerous states and the Department of Health's suggestion that masks be worn in public as a life-saving gesture, many people opt not to wear masks in public as a means of protecting themselves and others from COVID-19 infection [45].

An additional issue that has been brought up by the barangay enforcers is the lack of cooperation among the residents of the community. Because their cooperation may result in a better and more peaceful environment, it cannot be denied that constituents play an important role in maintaining peace and order at the barangay level.

\section{Conclusions and Recommendation}

In light of the research findings, it has been determined that the following conclusions can be drawn: Majority of the barangay enforcers belong to age above 55, male, married, elementary graduates, high school undergraduates, high school graduates, have 1 - 3 years of experience as barangay enforcers and receive only $1-3$ training which is related to their functions as enforcers. 
Table 7. Training plan.

\begin{tabular}{|c|c|c|c|c|c|c|c|}
\hline Training & Objectives & & Activities & $\begin{array}{c}\text { Resources/ } \\
\text { Budget }\end{array}$ & $\begin{array}{c}\text { Responsible } \\
\text { Persons }\end{array}$ & $\begin{array}{l}\text { Time } \\
\text { Frame }\end{array}$ & $\begin{array}{l}\text { Success } \\
\text { Indicator }\end{array}$ \\
\hline $\begin{array}{l}\text { Fire Safety and } \\
\text { Hazard } \\
\text { Identification }\end{array}$ & $\begin{array}{l}\text { This course is designed } \\
\text { to provide barangay } \\
\text { enforcers with the } \\
\text { knowledge and abilities } \\
\text { necessary to deal with } \\
\text { fires, fire dangers, and } \\
\text { emergencies in their } \\
\text { respective areas of } \\
\text { jurisdiction. }\end{array}$ & $\begin{array}{l}\square \\
\square \\
\square\end{array}$ & $\begin{array}{l}\text { Orientation } \\
\text { Lecture proper } \\
\text { Workshop }\end{array}$ & NEUST/P6600 & $\begin{array}{l}\text { College of } \\
\text { Criminology } \\
\text { Faculty/ } \\
\text { BFP Personnel }\end{array}$ & 1 Day & $\begin{array}{l}\text { The participants } \\
\text { will be better } \\
\text { prepared to deal } \\
\text { with fires, fire } \\
\text { dangers, and other } \\
\text { crises as a result of } \\
\text { this training }\end{array}$ \\
\hline $\begin{array}{l}\text { Intelligence } \\
\text { Gathering }\end{array}$ & $\begin{array}{l}\text { This course is designed } \\
\text { to provide barangay } \\
\text { enforcers with the } \\
\text { knowledge and skills } \\
\text { necessary to perform } \\
\text { surveillance on crime } \\
\text { breeding areas } \\
\text { within the barangay } \\
\text { boundaries. }\end{array}$ & $\begin{array}{l}\square \\
\square \\
\square\end{array}$ & $\begin{array}{l}\text { Orientation } \\
\text { Lecture proper } \\
\text { Workshop }\end{array}$ & NEUST/P6600 & $\begin{array}{l}\text { College of } \\
\text { Criminology } \\
\text { Faculty }\end{array}$ & 1 Day & $\begin{array}{l}\text { Each of the } \\
\text { participants will } \\
\text { leave with a solid } \\
\text { foundation of } \\
\text { information and } \\
\text { skills in } \\
\text { conducting } \\
\text { surveillance. }\end{array}$ \\
\hline $\begin{array}{l}\text { Crime Scene } \\
\text { Standard } \\
\text { Operating } \\
\text { Procedure (SOP) }\end{array}$ & $\begin{array}{l}\text { During this course, } \\
\text { barangay officials } \\
\text { will learn about the } \\
\text { legal requirements } \\
\text { they should follow } \\
\text { when reacting to } \\
\text { crime situations in } \\
\text { their jurisdiction. }\end{array}$ & $\begin{array}{l}\square \\
\square\end{array}$ & $\begin{array}{l}\text { Orientation } \\
\text { Lecture proper }\end{array}$ & NEUST/P6600 & PNP Personnel & 1 Day & $\begin{array}{l}\text { The participants } \\
\text { have a thorough } \\
\text { understanding of } \\
\text { the Standard } \\
\text { Operating } \\
\text { Procedures for } \\
\text { reacting to a } \\
\text { crime scene. }\end{array}$ \\
\hline $\begin{array}{l}\text { Standard First } \\
\text { Aid and Basic } \\
\text { Life Support }\end{array}$ & $\begin{array}{l}\text { This course will provide } \\
\text { the barangay enforcers } \\
\text { with basic first aid } \\
\text { skills, which are } \\
\text { essential for their duty. }\end{array}$ & $\begin{array}{l}\square \\
\square \\
\square\end{array}$ & $\begin{array}{l}\text { Orientation } \\
\text { Lecture proper } \\
\text { Workshop }\end{array}$ & NEUST/P6600 & $\begin{array}{l}\text { College of } \\
\text { Nursing Faculty }\end{array}$ & 1 Day & $\begin{array}{l}\text { Participants will } \\
\text { gain knowledge } \\
\text { and abilities in } \\
\text { basic first aid and } \\
\text { basic life support. }\end{array}$ \\
\hline $\begin{array}{l}\text { Self Defense } \\
\text { Techniques }\end{array}$ & $\begin{array}{l}\text { To strengthen/equip } \\
\text { barangay enforcers } \\
\text { with survival } \\
\text { techniques in the event } \\
\text { of a violent conflict. }\end{array}$ & $\begin{array}{l}\square \\
\square \\
\square\end{array}$ & $\begin{array}{l}\text { Orientation } \\
\text { Lecture proper } \\
\text { Workshop }\end{array}$ & NEUST/P6600 & $\begin{array}{l}\text { College of } \\
\text { Criminology } \\
\text { Faculty }\end{array}$ & 1 Day & $\begin{array}{l}\text { Participants will } \\
\text { gain information } \\
\text { and abilities in the } \\
\text { area of self-defense } \\
\text { techniques. }\end{array}$ \\
\hline $\begin{array}{l}\text { Patrol Standard } \\
\text { Operating } \\
\text { Procedure }\end{array}$ & $\begin{array}{l}\text { This course offers the } \\
\text { Barangay enforcer } \\
\text { knowledge and } \\
\text { expertise in patrol } \\
\text { conduct. }\end{array}$ & $\begin{array}{l}\square \\
\square\end{array}$ & $\begin{array}{l}\text { Orientation } \\
\text { Lecture proper }\end{array}$ & NEUST/P6600 & $\begin{array}{l}\text { College of } \\
\text { Criminology } \\
\text { Faculty }\end{array}$ & 1 Day & $\begin{array}{l}\text { The participants } \\
\text { will have a } \\
\text { thorough } \\
\text { understanding } \\
\text { of the standard } \\
\text { operating } \\
\text { procedure in the } \\
\text { field of patrolling. }\end{array}$ \\
\hline
\end{tabular}

Moreover, the researcher concludes based on the data gathered and analyzed that the respondents are highly knowledgeable when it comes to their duties and responsibilities. Furthermore, the respondents also asserted that they are highly knowledgeable about their role as first responders. They also claimed that they 
are highly knowledgeable in patrolling and hazard identification duties.

Therefore, the researcher recommends that barangay officials, together with their barangay enforcers, continue to carry out their responsibilities to the best of their abilities to safeguard the safety of their respective communities. Aside from these recommendations, the researcher suggests that barangay elected officials seek seminars and training from government agencies, state universities and colleges (SUCs), non-governmental organizations (NGOs), and other sectors that may provide seminars and training to maintain and improve the performance of their barangay enforcers in their roles as peacekeepers. Lastly, it is strongly recommended that the proposed training plan (Table 7) be funded and implemented to improve the knowledge and skills of the barangay enforcers in the areas that have been identified as needing improvement, as well as to provide continuous or sustainable training, which is critical to maintaining law and order in the society.

\section{Conflicts of Interest}

The author declares no conflicts of interest.

\section{References}

[1] Whetstone, J.T. (2002) Personalism and Moral Leadership: The Servant Leader with a Transforming Vision. Business Ethics: A European Review, 11, 385-392. https://doi.org/10.1111/1467-8608.00298

[2] Blanchard, K. and Hodges, P. (2005) Lead like Jesus: Lessons from the Greatest Leadership Role Model of All Time. W. Publishing Group, Nashville.

[3] Hunter, J. (2004) World's Most Powerful Leadership Principle: How to Become a Servant Leader. Crown Business, New York.

[4] Gagné, M. and Deci, E.L. (2005) Self-Determination Theory and Work Motivation. Journal of Organizational Behavior, 26, 331-362. https://doi.org/10.1002/job.322

[5] Grant, A.M. and Berry, J.W. (2011) The Necessity of Others is the Mother of Invention: Intrinsic and Prosocial Motivations, Perspective Taking, and Creativity. Academy of Management Journal, 54, 73-96. https://doi.org/10.5465/amj.2011.59215085

[6] Nikolaeva, M.A. (2015) Revisiting the Professional Training of Public Servants: Challenges of New Reality. Ars Administrandi, 3, 19-27.

[7] Hess, K.M. and Wrobleski, H.M. (2006) Police Operations, 5Shenton Way \#01-01 UIC Building Singapore 068808: Thomson Learning Asia, 60, 74, 477.

[8] Goldstein, H.C. (2000) Problem-Oriented Policing. McGraw Hill, Inc., New York.

[9] Walker, W. (2005) The Strengths and Weaknesses of Research Designs Involving Quantitative Measures. Journal of Research in Nursing, 10, 571-582. https://doi.org/10.1177\%2F136140960501000505

[10] Burns, N. and Grove, S.K. (2005) The Practice of Nursing Research: Conduct, Critique, and Utilization. 5th Edition, Elsevier, St Louis.

[11] Clark-Carter, D. (2010) International Encyclopedia of Education. 3rd Edition, Elsevier Science, Amsterdam.

https://www.sciencedirect.com/topics/mathematics/weighted-mean 
[12] Sumad-On, D. (2020) Effectiveness of Barangay Tanod in Crime Prevention in Central Region of Andaganan, Isabela. Journal of Critical Reviews, 7, 274-278. https://doi.org/10.31838/jcr.07.11.44

[13] Dick, P. and Jankowicz, D. (2001) A Social Constructionist Account of Police Culture and its Influence on the Representation and Progression of Female Officers. Policing: An International Journal of Police Strategies \& Management, 24, 181-199. https://doi.org/10.1108/13639510110390936

[14] Rabe-Hemp, C. (2007) Surviving the "All Boys Club": Policewomen and their Struggle for Acceptance. Policing. An International Journal of Police Strategies \& Management, 31, 251-270. https://doi.org/10.1108/13639510810878712

[15] Mina, J.C. (2019) Attainment of Cooperative Objectives and The Performance of Officers in Performing Their Management Functions: A Case of Cooperatives in Gapan City, Nueva Ecija. International Journal of Advanced Engineering, Management and Science, 5, 577-589. https://doi.org/10.22161/ijaems.511.2

[16] Gustaitis, P.J. and Guttieri, K. (2007) Finding the Missing Link to a Successful Philippine Counterinsurgency Strategy. Doctoral Dissertation, Naval Postgraduate School, Monterey.

[17] Caparas, D.L. (2000) Participation of the Public and Victims for More Fair and Effective Criminal Justice Administration in the Philippines. In: Iitsuka, H. and Findlay-Debeck, R., Eds., Resource Material Series, No. 56, NCJ-191475, Washington, DC, 241-258.

[18] Leones, C.S. (1993) Alternate Policing in the Philippines. In: Findlay, M. and Zvekic, U., Eds., Alternative Policing Style: Cross-Cultural Perspective, NCJ 146911, Kluwer Law International, Norwell, 101-108.

[19] Benitez, A.B. (2013) Bill gives Barangay Tanod's kids 50\% Discount in Tuition in SUCs. https://radyonatin.com/story.php?storyid $=4814$

[20] Williams, M.C. (2001) The Discipline of the Democratic Peace: Kant, Liberalism and the Social Construction of Security Communities. European Journal of International Relations, 7, 525-553. https://doi.org/10.1177\%2F1354066101007004006

[21] Rochon, T.R. (2014) Mobilizing for Peace: the Antinuclear Movements in Western Europe. Princeton University Press, Princeton.

[22] Pajarillo-Guadamor, M.L. (2016) Qualifications and Preparedness of Police Officers in Sustaining Peace and Order: It's Implication to Quality Service. International Journal of Advanced Research in Management and Social Sciences, 5, 148-162.

[23] Gapangada, A.B. (2014) An Assessment of the Role of Barangay Tanods in Mainstreaming Peace and Order. National Defense College of the Philippines, Manila. http://www.ndcp.edu.ph/index.php/library/thesis-1654/

[24] Philippine National Police (PNP) (2009) Lead PNP: Manual on Barangay Peacekeeping Operations and Barangay Peacekeeping Action Team.

https://pro1.pnp.gov.ph/Downloads/bpatmanual.pdf

[25] Verzosa, J.A. (2010) How to Handle Gender-Based Violence: A Manual for Police First Responders.

https://dpcr.pnp.gov.ph/portal/images/downloads/Publication/First\%20Responders \%20Manual.pdf

[26] Federal Highway Administration (2015) Traffic Incident Management: Gap Analysis Primer. Federal Highway Administration, Washington DC. https://ops.fhwa.dot.gov/publications/fhwahop15007/fhwahop15007.pdf

[27] Walker, L.E. (2007) The Role and Importance of First Responders in Dealing with 
Psychologically Disordered Individuals. In: First Responder's Guide to Abnormal Psychology, Springer, Boston, 1-11. https://doi.org/10.1007/978-0-387-35465-1 1

[28] Borck, N.C. (2020) Criminal Scene Investigation: Technical Working Group on Crime Scene Investigation.

https://www.fbi.gov/about-us/lab/forensic-science-communications/fsc/april2000/t wgcsi.pdf

[29] Price, T.G. and O’Neill, R.M. (2020) EMS Crime Scene Responsibility. StatPearls Publishing, Treasure Island.https://www.ncbi.nlm.nih.gov/books/NBK499999/

[30] Jetmore, L. (2016) Investigating Rape Crimes, Part 1: Guidelines for First Responders.

https://www.police1.com/police-products/investigation/evidence-management/artic les/investigating-rape-crimes-part-1-guidelines-for-first-responders-Szghj3goS1Wx $\underline{\mathrm{aXUu} /}$

[31] Fisher, J. (2015) The Role of First Responders: Responder Role in Disasters and other Emergencies.

http://www.communityemergencypreparedness.com/2015/11/the-role-of-first-resp onders.html

[32] Panhalkar, T. (2020) Roles of First Responder in Computer Forensics. Infosavvy.

[33] Spraggs, D. (2006) Crime Scene Response for the Patrol Officer. https://www.policemag.com/339486/crime-scene-response-for-the-patrol-officer

[34] Saron, R.G. (2018) Barangay Tanod System Revitalized. https://mindanaotimes.com.ph/2018/07/28/barangay-tanod-system-revitalized/

[35] Finch, C. (2018) What Is a Roving Officer? https://work.chron.com/roving-officer-24052.html

[36] Aspros, C. (2021) Why Is It Important to Report Hazards in the Workplace? https://www.uniprint.com.au/blogs/news/why-it-s-important-to-report-hazards-inthe-workplace

[37] Borck, N.C. (2020) A New App to Find, Document, and Report Hazards. Vol. 16, No. 8 LHSFNA Management.

https://www.lhsfna.org/index.cfm/lifelines/january-2020/a-new-app-to-find-docum ent-and-report-hazards/

[38] Sentry Security (2020) How Roving Patrol Security Provides a Handful of Safety Benefits. https://www.sentrysecurity.net/blog/2020/06/03/23

[39] Glück, J., König, S., Naschenweng, K., Redzanowski, U., Dorner, L., Straßer, I. and Wiedermann, W. (2016) How to Measure Wisdom: Content, Reliability, and Validity of Five Measures. Frontiers in Psychology, 4, 405.

https://doi.org/10.3389/fpsyg.2013.00405

[40] Kekes, J. (1983) Wisdom. American Philosophical Quarterly, 20, 277-286.

[41] Staudinger, U.M. and Glück, J. (2011) Psychological Wisdom Research: Commonalities and Differences in a Growing Field. Annual Review of Psychology, 62, 215-241. https://doi.org/10.1146/annurev.psych.121208.131659

[42] Al-Harthei1, H., Toth, V., Garib, A. and Mahmoud, S. (2017) Efficient Real-Time Allocation of Patrol Cars in Traffic Management. Proceedings of the 2nd World Congress on Civil, Structural, and Environmental Engineering (CSEE'17), Barcelona, 2-4 April 2017, Paper No. ICTE 105. https://doi.org/10.11159/icte17.105

[43] Zhang, S.Z. \& Benson, T.D. (1997) Cost-Effectiveness and Officer Morale of a Personally Assigned Vehicle Patrol Program: A Comparative Analysis. Policing. An International Journal, 20, 749-765. https://doi.org/10.1108/13639519710368134 
https://www.ojp.gov/ncjrs/virtual-library/abstracts/cost-effectiveness-and-officer-m orale-personally-assigned-vehicle

[44] Rampriya, R.S. and Suganya, R. (2021) Review on Various Communication Mechanism for Railway Patrol Using UAV. 5th International Conference on Trends in Electronics and Informatics (ICOEI), Tirunelveli, 3-5 June 2021, 617-625.

https://doi.org/10.1109/ICOEI51242.2021.9452943

[45] Gillespie, C. (2021) Why Do Some People Refuse to Wear a Face Mask in Public? https://www.health.com/condition/infectious-diseases/coronavirus/face-mask-refus e-to-wear-one-but-why?fbclid=IwAR3ZO34MDcpwwUfeEr9z2YvtgVoBLnfx 1Kal NP5fAsW754vpANCQGr9lyY 